\title{
The Influence of Soil Conditioning on Soil Infiltration Rate in Urban Facilities
}

\author{
Searphin Nugroho ${ }^{1, *}$, Wahyono Hadi $^{2}$ \\ ${ }^{1}$ Department of Environmental Engineering, Mulawarman University, Samarinda, East \\ Kalimantan, 75117, Indonesia \\ ${ }^{2}$ Department of Environmental Engineering, Adhi Tama Institute of Technology, Surabaya, \\ East Java, 60117, Indonesia
}

Received 10 June 2021/Revised 8 August 2021/Accepted 19 August 2021/Published 31 August 2021

\begin{abstract}
Several attempts have been made to increase the permeable area in the cities, which include the building of green facilities such as parks and urban forests. Since these areas were built with soil compaction, the potential for infiltrating water differs compared with the natural green area. Therefore, this research aims to analyze the influence of soil conditioning on the constant infiltration rate using variables such as soil compaction, texture, and the presence of vegetation cover in urban facilities. The data used were obtained through field infiltration measurement using a single ring infiltrometer. In this research, the analysis carried out includes soil texture, Horton equation, the difference between conditioned soils and control plots, and USDA hydrologic soil classifications. The results showed that all variables (soil compaction, the presence of vegetation cover, and soil texture) have a significant effect on the constant infiltration rate. Based on the soil conditioning, the infiltration rate is increased on the vegetated plots and decreased on the plots with the combination of vegetation and compaction, as well as the compacted plots. Furthermore, the effect of vegetation cover is more significant in silt loam textured soil, while the influence of compaction is more on clay textured soil. The potential constant infiltration rate on the plots of similar characteristics with green urban areas are on K2 and L2 with $2.698 \mathrm{~mm} / \mathrm{h}$ and $1.525 \mathrm{~mm} / \mathrm{h}$, respectively. Therefore, these plots have a moderate runoff potential based on USDA hydrologic soil classification.
\end{abstract}

Keywords: Compaction; Infiltration; Soil conditioning; Urban facilities

\section{Introduction}

All processes related to defect in the earth's surface are influenced by human activities, which are responsible for the landform changes, especially during the environmental planning that involves public policies (Sucahyanto et al., 2018). The global development of urban areas due to an increase in population has continuously threatened natural dynamics, the availability of resources, and environmental quality (McGrane, 2016; Marie Mireille et al., 2019). Moreover, changes in land cover have caused some problems such as soil degradation which depends on intensity, pattern, and types of land cover change,

*Corresponding author.

Email address : searphin91@gmail.com (Searphin Nugroho) 
Searphin Nugroho \& Wahyono Hadi / Geosfera Indonesia 6 (2), 2021, 222-240

namely depletion of nutrients, decrease in infiltration capacity and moisture content of the soil (Marie Mireille et al., 2019).

Infiltration is one of the major components of the hydrological process by which water enters the soil profile from the surface (Gundalia, 2018). In this process, the water entering into the soil are from precipitation, irrigation, leaf drip, and stem flow, or runoff which was routed over the land surface and reinfiltrates (Vereecken et al., 2019). Therefore, infiltration is an important main source of groundwater, which plays a major role in the ecological and geological environment, as well as economic and social development (Zhang et al., 2020). The reduction of the permeable area from these land cover changes, especially in urban areas such as land hardening and vadose thickening has caused many problems which include decreased precipitation infiltration, soil erosion, and increased runoff that leads to flooding (Apollonio et al., 2016; Zhang et al., 2020). Meanwhile, the reduced infiltration rate has been proven from some researches by Gregory et al. (2006) and Zemke et al. (2019). These researches analyzed the effect of soil compaction on infiltration rate due to the activities of urban area expansion or development, and the results showed that soil compaction reduced soil infiltration rate drastically, which leads to a possibility of increased runoff, especially during heavy rainfall.

Furthermore, several types of researches have been conducted to analyze the effect of land cover use or change on soil infiltration. One of these was research by Regüés et al. (2017), that analyzed the effect of various factors such as land use, vegetation cover, soil and bedrock characteristics, moisture and altitude, on soil infiltration in three different environments in Spain. The results of the research showed that land with vegetation cover in normal and burnt conditions has a higher soil infiltration rate compared with the unvegetated vacant land. Based on land use, vegetation cover is one of the most important factors that influence soil infiltration rate.

There have been limited studies on the combination effect between soil compaction and types, as well as land cover, especially vegetation on constant infiltration rate. This is due to the infrastructural development of the urban areas, especially public facilities, and some considerations such as soil types and structure which are different from one area to another. In addition to creating awareness on the present needs of green areas or space in urban areas, some public facilities such as parks are built (Hwang et al., 2020), which involve soil compaction in the process and depend on factual conditions in the field and client demands. This showed that the constant soil infiltration rate and the potential runoff from these facilities differed compared with more natural or uncompacted green space, even between other parks or facilities inside a city, which affect the development of urban drainage. 
Therefore, this research aims to calculate and analyze the influence of the combinations on soil conditioning which consists of a type, land cover, and compaction variations on measured constant soil infiltration rate in urban facilities. Also, to determine the potential constant soil infiltration capacity and the runoff on the plots of similar characteristics with the compacted green areas.

\section{Methods}

\subsection{Initial Data Collection and Field Studies}

The pre-research data collection was needed to determine the research location, which was the soil type map of Surabaya City from its respective departments and Google Maps for the information of urban facilities in the city. These data were used as a basis for the field analysis and the selection of the most ideal locations for testing soil infiltration. In this research, the chosen locations were Kenjeran Beach Amusement Park and Lempung Urban Forest, Surabaya, which are shown in Figure 1.

The reasons for choosing these two urban facilities for this research are as follows: a) each of the test fields is located on different soil types based on the map in Surabaya City, where Kenjeran Beach Amusement Park is on the hydromorphic alluvial soil and Lempung Urban Forest on gray alluvial, b) the variations on the land cover, where some parts of these locations are covered by vegetation, while others are not covered (vacant), and c) easy access to clean water for soil infiltration tests, as anticipation when the time to achieve constant infiltration rate is longer than expected. At the test fields, some soils were sampled at $10-30$ $\mathrm{cm}$ from the surface and brought to the laboratory to determine the distribution of soil particles based on the Indonesian National Standards (SNI 3423:2008). Moreover, the soil texture of the test plots was analyzed by matching the laboratory data with the USDA soil textural triangle. Based on this soil triangle, there were 12 types of soil textures determined by the distribution of the soil particles. These types of textures were clay, sandy clay, silty clay, sandy clay loam, clay loam, silty clay loam, loam, sandy loam, loamy sand, sand, silt loam, and silt (Schoeneberger et al., 2012). The visualization of the soil texture variations is shown in Figure 2. 
Searphin Nugroho \& Wahyono Hadi / Geosfera Indonesia 6 (2), 2021, 222-240

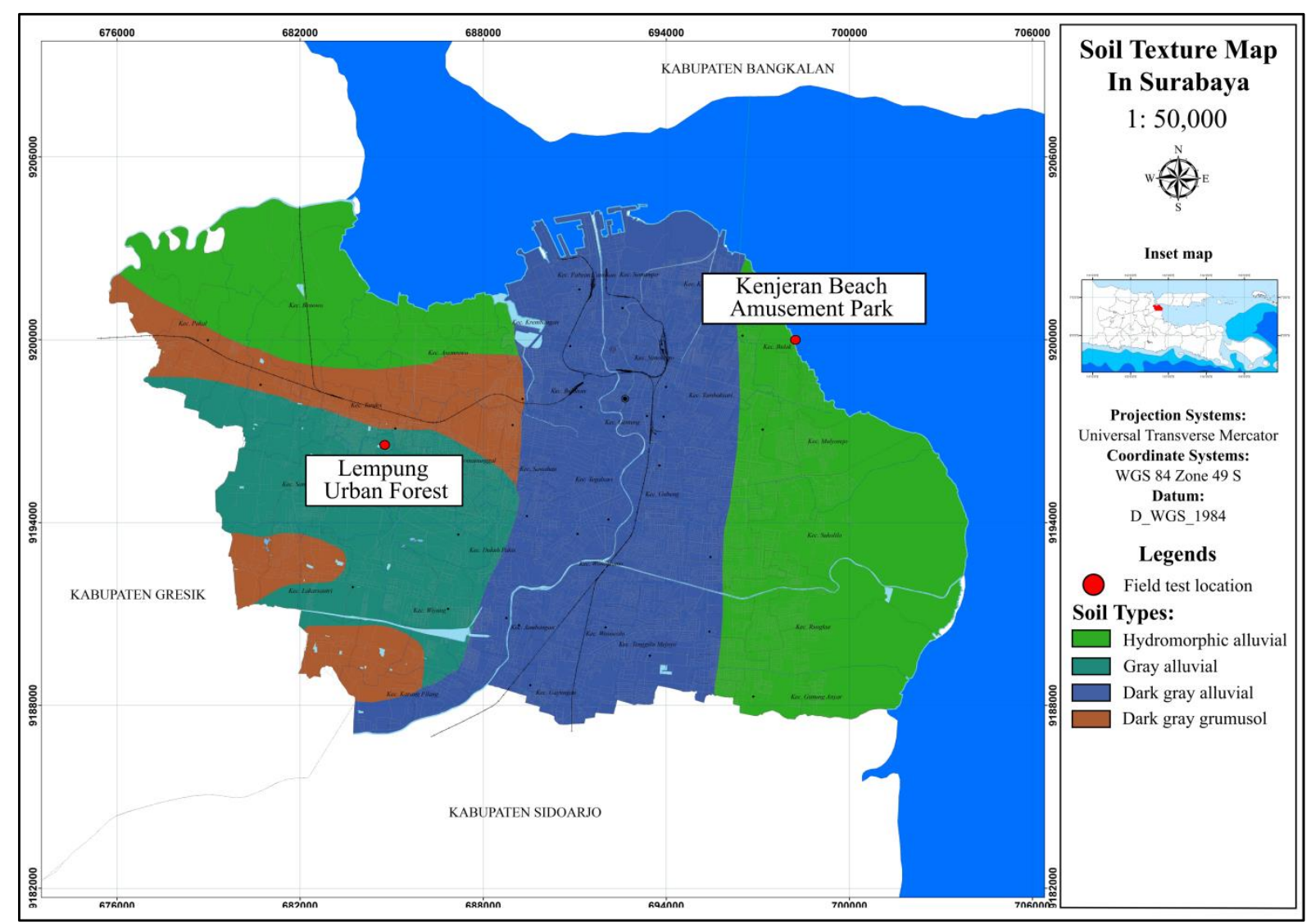

Figure 1. The test fields on the soil type map in Surabaya City

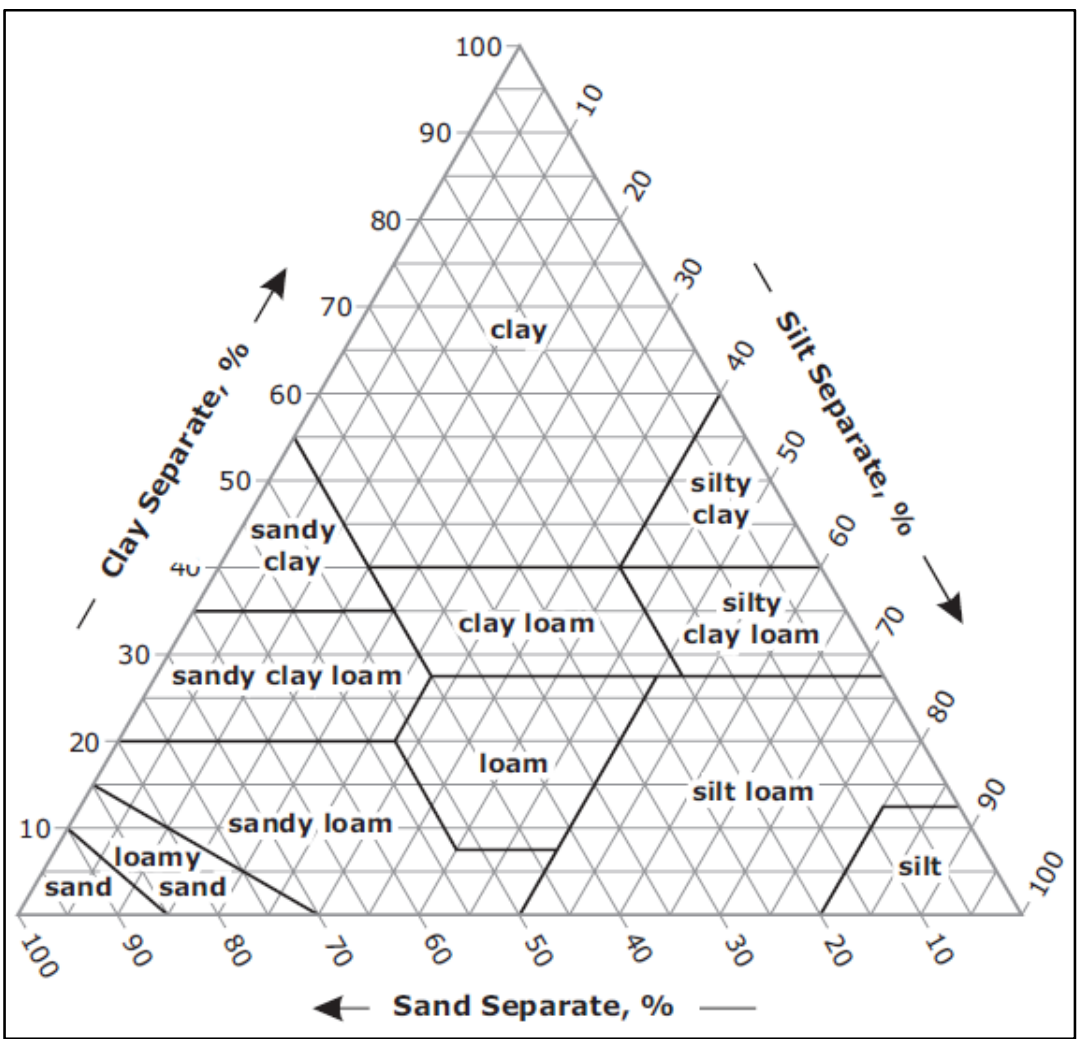

Figure 2. The USDA soil textural triangle (Schoeneberger et al., 2012) 


\subsection{Test Field Conditioning}

In this research, each of the test locations was divided into four test plots with the size of $1 \times 1 \mathrm{~m}$. For the conditioning of the test plots, the variables to be analyzed were considered, namely soil type, land cover, and soil compaction. The variations of the plots are shown in Table 1.

Table 1. Plot conditioning in test fields

\begin{tabular}{ccccc}
\hline \multirow{2}{*}{ Numb. } & \multirow{2}{*}{ Location } & \multicolumn{2}{c}{ Plot conditioning } & \multirow{2}{*}{ Plot code } \\
\cline { 3 - 4 } & \multirow{3}{*}{\begin{tabular}{c} 
Vegetation \\
\multirow{2}{*}{ Kenjeran Beach Amusement Park }
\end{tabular}} & $\checkmark$ & - & K1 \\
& & - & $\checkmark$ & K2 \\
& & - & $\checkmark$ & K3 \\
& \multirow{2}{*}{2} & $\checkmark$ & - & K4 \\
& Lempung Urban Forest & $\checkmark$ & $\checkmark$ & L1 \\
& & - & - & L3 \\
& & - & $\checkmark$ & L4 \\
\hline
\end{tabular}

Based on Table 1 above, there are four types of plots with different soil conditioning in each location, which consist of: a) control plots (without vegetation cover and compaction, plot K3, and L3), b) plots with vegetation cover only (K1 and L1), c) plots with compaction only (K2 and L2), and d) plots with vegetation cover and compaction (K4 and L4).

In both test fields, some parts had no cover on the surface, therefore, it was not necessary to cut the vegetation in these places. For the test plot compaction, four of the eight plots were compacted using a stamper with durations of approximately 30 seconds, which was adopted from Gregory et al. (2006). The soil types on Kenjeran Beach Amusement Park and Lempung Urban Forest are different from each other. Therefore, the soil type that was most affected by the conditioning was also analyzed.

\subsection{Soil Infiltration Measurements}

Soil infiltration rate measurements at test fields were conducted using a single-ring infiltrometer and a ruler to observe the change in the surface water level inside the ring, every five minutes. Furthermore, water was added to the original surface water level in the ring every five minutes until its rate became constant. The documentation of the measurements is shown in Figure 3. 


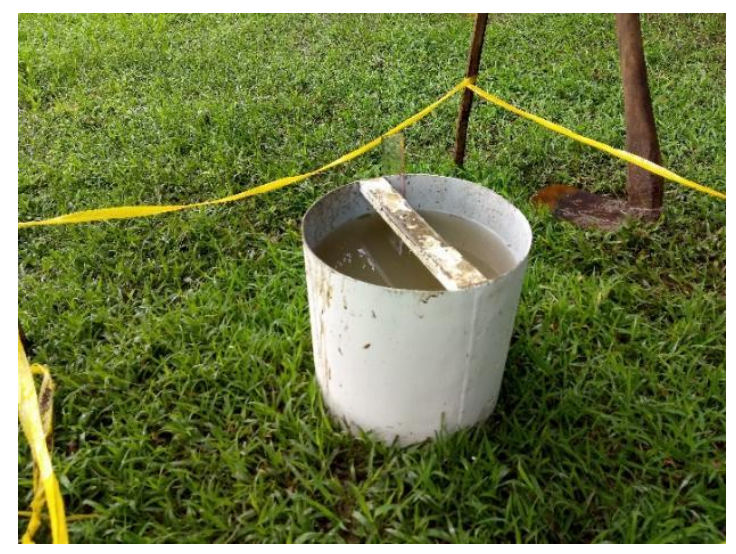

Figure 3. The soil infiltration measurement on the test plot

\subsection{Modeling the Soil Infiltration Rate Curve}

From the measurements on the test plots, the curve of soil infiltration rate or capacity is modeled using the Horton Equation. According to Qing et al. (2020), the soil infiltration rate on the specific time, $\mathrm{f}$, is calculated as follows:

$$
f=f_{c}+\left(f_{0}-f_{c}\right) \cdot e^{-k t}
$$

Where $f$ is the infiltration rate or capacity $(\mathrm{mm} / \mathrm{h}), \mathrm{f}_{0}$ is the initial infiltration rate or capacity $(\mathrm{mm} / \mathrm{h}), \mathrm{f}_{\mathrm{c}}$ is the constant infiltration rate or capacity $(\mathrm{mm} / \mathrm{h})$, e is the exponential value of approximately $2.718, \mathrm{k}$ is the value that indicates the decrease of soil infiltration rate or capacity, and $\mathrm{t}$ is the duration of the infiltration (h). The Eq. 1 above can be rearranged to determine the value of $\mathrm{k}$, which is written as follows:

$$
\ln \left(f-f_{c}\right)=-k t+\ln \left(f_{0}-f_{c}\right)
$$

By following the general formula of the single linear equation, where $\ln \left(f-f_{c}\right)$ is the output value, $-k$ as the gradient value or $m$, and $\ln \left(f_{0}-f_{c}\right)$ is the value of the constant, the Eq. 2 is written as follows:

$$
k=-\frac{\left[\ln \left(f-f_{c}\right)-\ln \left(f_{0}-f_{c}\right)\right]}{t}
$$

Due to the infiltration rate measurement in the field only a few minutes after time $\mathrm{t}=$ 0 , the value of the initial infiltration rate at time $t=0\left(f_{0}\right)$ is unknown. Therefore, to obtain the value of $\mathrm{f}_{0}$, a curve was made between the infiltration rate measurement data against time. Furthermore, Microsoft Excel and the included Solver add-in were used to adjust and extend the curve until it reached the $\mathrm{Y}$-axis intersection, where $\mathrm{t}=0$. After the data were obtained, the modeling of infiltration capacity was performed using all the steps explained above. 


\subsection{Analysis Stage}

\subsubsection{Influence of the Soil Conditioning on the Constant Soil Infiltration Rate}

In this analysis, all the measured constant soil infiltration rates from the test plots with soil conditioning such as K1, L1, K2, L2, K4, and L4, are compared with the control plots which are K3 and L3. These comparisons are needed to determine the influences from the research variables such as the soil types, soil compaction, and the presence of vegetation cover. The difference of the constant infiltration rates $(\Delta f)$ is calculated as follows:

$$
\Delta \mathrm{f}=\frac{\mathrm{f}_{\mathrm{sc}}-\mathrm{f}_{\mathrm{ctrl}}}{\mathrm{f}_{\mathrm{ctrl}}} \times 100 \%
$$

Where $\Delta \mathrm{f}$ is the infiltration rate or capacity difference $(\%), \mathrm{f}_{\mathrm{sc}}$ is the constant infiltration rate or capacity on the plots with soil conditioning $(\mathrm{mm} / \mathrm{h})$, and $\mathrm{f}_{\mathrm{ctrl}}$ is the constant infiltration rate or capacity on the control plots $(\mathrm{mm} / \mathrm{h})$.

2.5.2 Comparison between the Infiltration Rate Measurements with Modeled Infiltration Rate

All the soil infiltration measurements from test plots were compared with all the modeled infiltration rates based on the Horton equation, using the modeled one as the reference with OriginLab. This was conducted to analyze the average difference or gap between the predicted infiltration rate calculated by the Horton equation with the actual rate in the test plots using the same time frame from the initial to when the rate becomes constant.

\subsubsection{Potential Constant Infiltration Capacity from the Test Plots}

The values of potential constant infiltration capacity from all tested plots were determined from the calculation process when the soil infiltration capacity was modeled using Horton equations on Eq.1-Eq.3, especially when the infiltration capacity became constant. These values were classified based on the USDA hydrologic soil group to determine the fastness or slowness of the rates and the potential to generate surface runoff in rainy conditions. According to Satheeshkumar et al. (2017), the information about USDA hydrologic soil group is shown in Table 2 .

Table 2. USDA hydrologic soil group (Satheeshkumar et al., 2017)

\begin{tabular}{cccc}
\hline $\begin{array}{c}\text { Hydrologic soil } \\
\text { (HSG) }\end{array}$ & $\begin{array}{c}\text { Runoff } \\
\text { potential }\end{array}$ & $\begin{array}{c}\text { Water } \\
\text { transmission }\end{array}$ & $\begin{array}{c}\text { Final infiltration } \\
(\mathbf{m m} / \mathbf{h})\end{array}$ \\
\hline Group A & Low & High rate & $>7.5$ \\
Group B & Moderate & Moderate rate & $3.8-7.5$ \\
Group C & Moderate & Moderate rate & $1.3-3.8$ \\
Group D & High & Low rate & $<1.3$ \\
\hline
\end{tabular}




\section{Results and Discussion}

\subsection{The Test Fields Conditions and Their Soil Textures}

As previously mentioned, there are two locations to be tested in this research, which are Kenjeran Beach Amusement Park at the northeast and Lempung Urban Forest at the west side of Surabaya city. Based on the soil type map of Surabaya, Kenjeran Beach Amusement Park lies on the hydromorphic alluvial, while the Lempung Urban Forest area is on the gray alluvial.

During the research, it was observed that the soil at both locations was not precisely natural, especially on the surface part. This was because the places were buried by the soils that came from the outside. At Kenjeran Beach Amusement Park, the soil is a combination of the padas pile on the bottom part covered by the silt loam texture on its surface, while at Lempung Urban Forest, some clay soils were from the excavation of boozem (detention pond) around the forest. Therefore, a further investigation of the soil texture is recommended. The results of the particle compositions from the sampled soil in all plots are shown in Table 3.

Table 3. Soil texture of the test plots

\begin{tabular}{llcccc}
\hline Plot & \multicolumn{1}{c}{ Soil Texture } & $\begin{array}{c}\text { Gravel } \\
(\boldsymbol{\%})\end{array}$ & $\begin{array}{c}\text { Sand } \\
(\boldsymbol{\%})\end{array}$ & $\begin{array}{c}\text { Silt } \\
(\boldsymbol{\%})\end{array}$ & $\begin{array}{c}\text { Clay } \\
(\boldsymbol{\%})\end{array}$ \\
\hline K1 & $\begin{array}{l}\text { Silt loam }(0-25 \mathrm{~cm}) \\
\text { Landfill }(26-100 \mathrm{~cm})\end{array}$ & 0.011 & 0.120 & 76.242 & 23.627 \\
& $\begin{array}{l}\text { Silt loam }(0-25 \mathrm{~cm}) \\
\text { K2 }\end{array}$ & 0.167 & 4.707 & 74.428 & 20.698 \\
& Landfill $(26-100 \mathrm{~cm})$ & & & & \\
K3 & Silt loam $(0-30 \mathrm{~cm})$ & 5.387 & 13.960 & 64.026 & 16.627 \\
& Landfill $(31-100 \mathrm{~cm})$ & & & & \\
K4 & Silt loam $(0-30 \mathrm{~cm})$ & 0.423 & 1.843 & 81.456 & 16.278 \\
L1 & Landfill $(31-100 \mathrm{~cm})$ & & & & \\
L2 & Clay $(0-100 \mathrm{~cm})$ & 0.284 & 20.308 & 19.376 & 60.031 \\
L3 & Clay $(0-100 \mathrm{~cm})$ & 0.980 & 31.285 & 11.092 & 56.643 \\
L4 & Clay $(0-100 \mathrm{~cm})$ & 0.713 & 14.759 & 23.166 & 61.362 \\
\hline
\end{tabular}

Based on Table 3, from the soil texture analysis in the laboratory, all the samples from the test plots were dominated by fine-sized particles. Most of the sampled soils from Kenjeran Beach Amusement Park were silt particles at approximately $64.03-81.46 \%$. Meanwhile, the clay particles were the dominant sampled soils in Lempung Urban Forest with approximately $56.46-61.36 \%$. Based on the soil texture classifications, Kenjeran Beach Amusement Park was classified as silt loam and Lempung Urban Forest as clay. The detailed visualizations of the soil texture from all test plots are shown in Figure 4. 


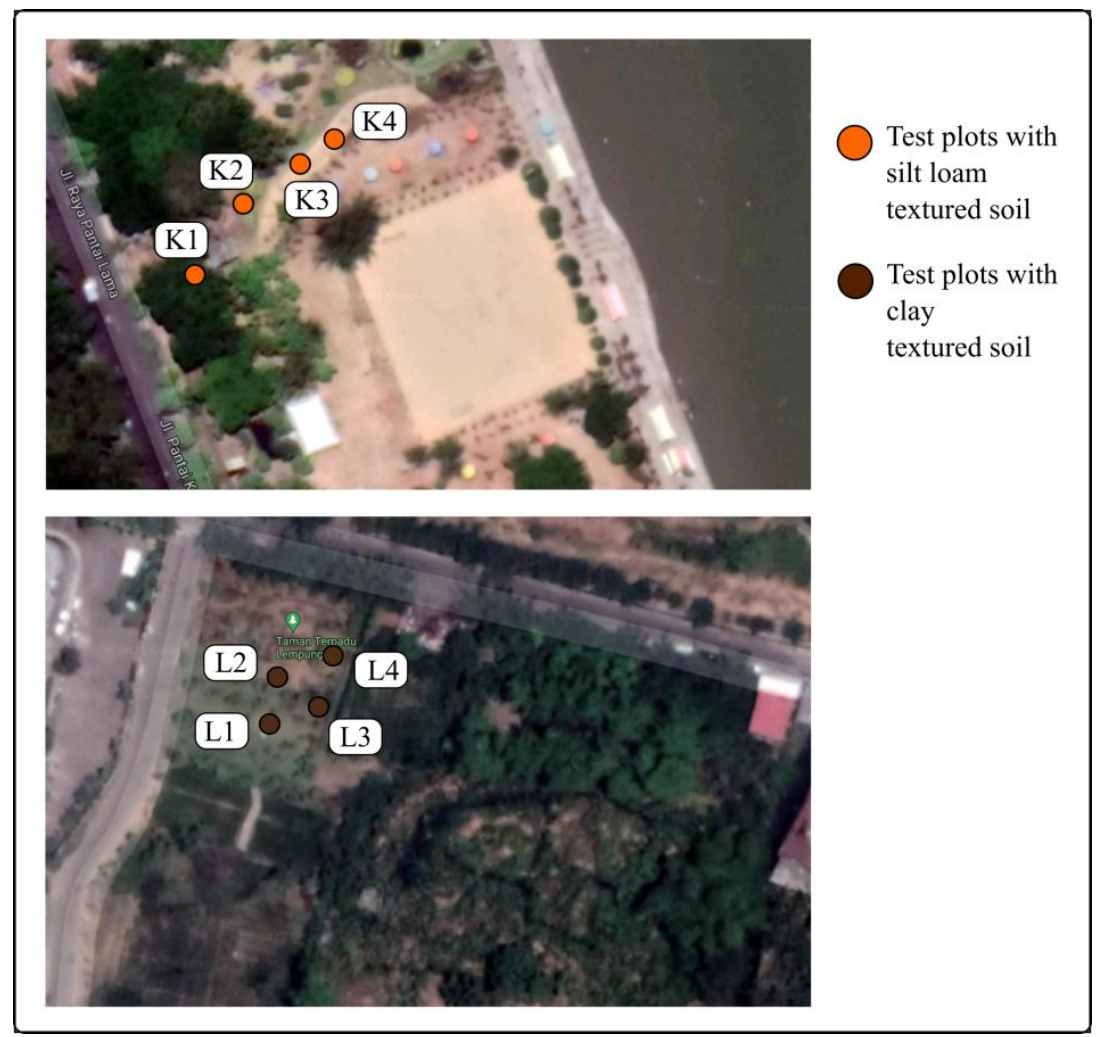

Figure 4. The detailed locations of all test plots in their respective soil textures

\subsection{Soil Infiltration Measurements on the Test Plots}

Soil infiltration measurements were carried out to determine the ability of the soil surface to drain water. In this research, the measurements were analyzed with the influence of the soil conditioning, such as compaction, presence of the vegetation cover, and soil types. The results of the infiltration rate measurements in the Kenjeran Beach Amusement Park are shown in Table 4, while the Lempung City Forest is shown in Table 5.

Table 4. Soil infiltration measurements in Kenjeran Beach Amusement Park

\begin{tabular}{|c|c|c|c|c|c|c|c|c|c|c|c|}
\hline \multicolumn{3}{|c|}{ K1 Plot } & \multicolumn{3}{|c|}{ K2 Plot } & \multicolumn{3}{|c|}{ K3 Plot } & \multicolumn{3}{|c|}{ K4 Plot } \\
\hline $\begin{array}{c}\Delta \mathrm{t} \\
(\mathrm{min})\end{array}$ & $\begin{array}{c}\Delta \mathrm{h} \\
(\mathrm{mm})\end{array}$ & $\begin{array}{c}\mathrm{f} \\
(\mathrm{mm} / \mathrm{h})\end{array}$ & $\begin{array}{c}\Delta \mathrm{t} \\
(\mathrm{min})\end{array}$ & $\begin{array}{c}\Delta \mathrm{h} \\
(\mathrm{mm})\end{array}$ & $\begin{array}{c}\mathrm{f} \\
(\mathrm{mm} / \mathrm{h})\end{array}$ & $\begin{array}{c}\Delta \mathrm{t} \\
(\mathrm{min})\end{array}$ & $\begin{array}{c}\Delta \mathrm{h} \\
(\mathrm{mm})\end{array}$ & $\begin{array}{c}\mathrm{f} \\
(\mathrm{mm} / \mathrm{h})\end{array}$ & $\begin{array}{c}\Delta \mathrm{t} \\
(\mathrm{min})\end{array}$ & $\begin{array}{c}\Delta \mathrm{h} \\
(\mathrm{mm})\end{array}$ & $\begin{array}{c}\mathrm{f} \\
(\mathrm{mm} / \mathrm{h})\end{array}$ \\
\hline 15 & 6 & 24 & 5 & 1.5 & 18 & 15 & 4 & 16 & 15 & 2.5 & 10 \\
\hline 15 & 5.5 & 22 & 5 & 1 & 12 & 15 & 2 & 8 & 15 & 2 & 8 \\
\hline 15 & 5 & 20 & 5 & 1 & 12 & 15 & 1 & 4 & 15 & 1.5 & 6 \\
\hline 15 & 4 & 16 & 5 & 0.5 & 6 & 30 & 1 & 1.99 & 15 & 1 & 6 \\
\hline 15 & 3 & 12 & 15 & 0.5 & 1.99 & 30 & 1 & 1.99 & 15 & 1 & 5 \\
\hline 15 & 3 & 12 & 15 & 0.5 & 1.99 & 30 & 1 & 1.99 & 15 & 1 & 5 \\
\hline 15 & 2.5 & 10 & 15 & 0.5 & 1.99 & & & & 45 & 1 & 1.33 \\
\hline 15 & 2 & 8 & & & & & & & 45 & 1 & 1.33 \\
\hline 15 & 2 & 8 & & & & & & & 45 & 1 & 1.33 \\
\hline 15 & 2 & 8 & & & & & & & & & \\
\hline$\Sigma \mathbf{t}=1$ & & & $\Sigma \mathrm{t}=6$ & & & $\Sigma \mathbf{t}=1$ & & & $\Sigma \mathrm{t}=2$ & & \\
\hline
\end{tabular}


Table 5. Soil infiltration measurements in Lempung Urban Forest

\begin{tabular}{|c|c|c|c|c|c|c|c|c|c|c|c|}
\hline \multicolumn{3}{|c|}{ L1 Plot } & \multicolumn{3}{|c|}{ L2 Plot } & \multicolumn{3}{|c|}{ L3 Plot } & \multicolumn{3}{|c|}{ L4 Plot } \\
\hline $\begin{array}{c}\Delta \mathrm{t} \\
(\mathrm{min})\end{array}$ & $\begin{array}{c}\Delta \mathrm{h} \\
(\mathrm{mm})\end{array}$ & $\begin{array}{c}\mathrm{f} \\
(\mathrm{mm} / \mathrm{h})\end{array}$ & $\begin{array}{c}\Delta \mathrm{t} \\
(\mathrm{min})\end{array}$ & $\begin{array}{c}\Delta \mathrm{h} \\
(\mathrm{mm})\end{array}$ & $\begin{array}{c}\mathrm{f} \\
(\mathrm{mm} / \mathrm{h})\end{array}$ & $\begin{array}{c}\Delta \mathrm{t} \\
(\mathrm{min})\end{array}$ & $\begin{array}{c}\Delta \mathrm{h} \\
(\mathrm{mm})\end{array}$ & $\begin{array}{c}\mathrm{f} \\
(\mathrm{mm} / \mathrm{h})\end{array}$ & $\begin{array}{c}\Delta \mathrm{t} \\
(\mathrm{min})\end{array}$ & $\begin{array}{c}\mathrm{h} \\
(\mathrm{mm})\end{array}$ & $\begin{array}{c}\mathrm{f} \\
(\mathrm{mm} / \mathrm{h})\end{array}$ \\
\hline 20 & 2 & 6 & 15 & 0.5 & 2 & 60 & 3 & 3 & 15 & 0.5 & 2 \\
\hline 20 & 1.5 & 4.5 & 120 & 0.25 & 0.125 & 60 & 2 & 2 & 120 & 0.125 & 0.0625 \\
\hline 20 & 1 & 3 & 120 & 0.25 & 0.125 & 60 & 2 & 2 & 120 & 0.125 & 0.0625 \\
\hline 20 & 0.5 & 1.5 & 120 & 0.25 & 0.125 & 60 & 1 & 1 & 120 & 0.125 & 0.0625 \\
\hline 20 & 0.5 & 1.5 & & & & 60 & 1 & 1 & & & \\
\hline 20 & 0.5 & 1.5 & & & & 60 & 1 & 1 & & & \\
\hline \multicolumn{3}{|c|}{$\Sigma t=120$} & \multicolumn{3}{|c|}{$\Sigma t=375$} & $\Sigma \mathbf{t}=\mathbf{3}$ & & & \multicolumn{3}{|c|}{$\Sigma t=375$} \\
\hline $\begin{array}{l}\text { Note } \\
\Delta \mathrm{t}= \\
\Delta \mathrm{h}= \\
\mathrm{f}= \\
S \mathrm{t}=\end{array}$ & 19 & rate & 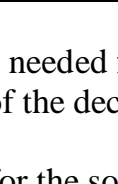 & . & 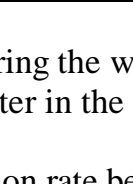 & le- & nfil & ter & efil & & \\
\hline
\end{tabular}

Based on Table 4, the highest initial infiltration rate measurement in the Kenjeran Beach Amusement Park area of the tested four plots was K1 with approximately $24 \mathrm{~mm} / \mathrm{h}$. This was successively followed by K2, K3, and $\mathrm{K} 4$ plots with $18 \mathrm{~mm} / \mathrm{h}, 16 \mathrm{~mm} / \mathrm{h}$, and 10 $\mathrm{mm} / \mathrm{h}$, respectively. For the constant infiltration rate, the highest plot among the four was $\mathrm{K} 1$, with approximately $8 \mathrm{~mm} / \mathrm{h}$, followed by $\mathrm{K} 2, \mathrm{~K} 3$, and $\mathrm{K} 4$ with $1.99 \mathrm{~mm} / \mathrm{h}, 1.99 \mathrm{~mm} / \mathrm{h}$, and $1.33 \mathrm{~mm} / \mathrm{h}$, respectively.

The results of the Lempung Urban Forest area as shown in Table 5, indicated that the highest initial infiltration rate measurement from the tested four plots was the L1, with approximately $6 \mathrm{~mm} / \mathrm{h}$. Consequently, it was followed by L3, L2, and L4 plots with $3 \mathrm{~mm} / \mathrm{h}$, $2 \mathrm{~mm} / \mathrm{h}$, and $2 \mathrm{~mm} / \mathrm{h}$, respectively. For the constant infiltration rate, the highest plot among the four was L1 with approximately $8 \mathrm{~mm} / \mathrm{h}$, followed by L3, L2, and L4 with $1 \mathrm{~mm} / \mathrm{h}, 0.125$ $\mathrm{mm} / \mathrm{h}$, and $0.0625 \mathrm{~mm} / \mathrm{h}$, respectively.

Based on the correlation between the constant infiltration rate with soil textures from both locations, Kenjeran Beach Amusement Park that has silt loam textured soil has a higher constant infiltration rate compared with Lempung Urban Forest that has clay textured soil, when conditioned with the same treatment such as being vegetated, compacted, etc. This is because the dominant silt particles in Kenjeran Beach Amusement Park have larger pores, which caused higher infiltration rates. Similarly, this pattern occurred in research by Folorunso \& Aribisala (2018) which showed that soil with higher and finer particle compositions has a lower rate and accumulated infiltration. This was conducted using a sandy clay textured soil with higher particles compared with others with higher sand particles. In research by Patle et al. (2019), the infiltration rate measurements were measured in the loamy 
sand and sandy loam textured soil that has a lower average infiltration rate because of the higher clay particles compared with loamy sand textured soil.

According to Table 4 and Table 5, the total time needed for the soil to reach the saturated state $(\Sigma \mathrm{t})$ on all test plots varies from one condition to another. The longest $\Sigma \mathrm{t}$ overall were on the L2 and L4 plots with approximately 375 minutes, which have clay textured soil. The shortest $\Sigma \mathrm{t}$ overall was on the K2 plot with approximately 65 minutes, which has silt loam textured soil. Meanwhile, the time difference needed to reach the constant infiltration rate condition between each plot was caused by several factors including soil type, texture, and anthropic interventions such as compaction. Moreover, Coutinho et al. (2020) stated that the field with finer soil particles that are often used by society tends to have a smaller infiltration rate and the time needed to reach its saturated condition is longer than expected. As previously mentioned, the test fields in this research are the urban facilities, where human activities and social interactions always happen. Also, these locations consist of the soil with fine-sized particles. These results are also confirmed in research by Ma et al. (2016) which showed that different soil textures have varied periods needed to reach the saturated condition, where sandy soils have a shorter time compared with loamy soil that has a smaller particle size.

\subsection{The Influence of Soil Conditioning on Constant Soil Infiltration Rate}

The influences of the combinations of the research variables such as the soil types, compaction, and the presence of vegetation cover with the constant soil infiltration rate were analyzed on the selected urban facilities in Kenjeran Beach Amusement Park and Lempung Urban Forest in Surabaya City. Each location has a control plot with the condition of without soil compaction and vegetation cover on the surface (vacant land), which are K3 in Kenjeran Beach Amusement Park and L3 plot in Lempung Urban Forest. The comparison of the effect of soil treatment on the constant infiltration rate is shown in Table 6.

Table 6. Comparisons of the constant soil infiltration rate based on different soil conditioning

\begin{tabular}{|c|c|c|c|c|c|}
\hline Test plot & $\begin{array}{c}f_{s c} \\
(\mathbf{c m} / \mathbf{h})\end{array}$ & Soil conditioning & Control plot & $\begin{array}{c}f_{c t r l} \\
(\mathbf{c m} / \mathbf{h})\end{array}$ & $\begin{array}{c}\Delta f \\
(\%)\end{array}$ \\
\hline $\mathrm{K} 1$ & 8.000 & Vegetated silt loam soil & $\mathrm{K} 3$ & 1.990 & +302 \\
\hline $\mathrm{K} 2$ & 1.990 & $\begin{array}{l}\text { Vegetated and compacted } \\
\text { silt loam soil }\end{array}$ & $\mathrm{K} 3$ & 1.990 & 0 \\
\hline K4 & 1.333 & Compacted silt loam soil & K3 & 1.990 & -33.16 \\
\hline L1 & 1.500 & Vegetated clay soil & L3 & 1.000 & +50 \\
\hline L2 & 0.125 & $\begin{array}{c}\text { Vegetated and compacted } \\
\text { clay soil }\end{array}$ & L3 & 1.000 & -87.5 \\
\hline $\mathrm{L} 4$ & 0.063 & Compacted clay soil & L3 & 1.000 & -97 \\
\hline $\begin{array}{l}\text { Note: } \\
\Delta f \quad=\text { The in } \\
f_{s c}=\text { The cc } \\
f_{c t r l}=\text { The cc }\end{array}$ & $\begin{array}{l}\text { ion rate or } \\
t \text { infiltrati } \\
t \text { infiltrati }\end{array}$ & $\begin{array}{l}\text { city difference } \\
\text { or capacity on the plots with } \\
\text { or capacity on the control pl }\end{array}$ & nditioning & & \\
\hline
\end{tabular}


Based on Table 6, there are differences in the constant infiltration rate related to the effect of the research variable or soil conditioning on the test plots, whether these conditionings increased or decreased the soil infiltration rate. The maximum increased $\Delta \mathrm{f}$ value on the conditioned test plots with silt loam soil was $302 \%$ on the K1 plot with vegetated silt loam soil, while the maximum decreased $\Delta \mathrm{f}$ value was $33.16 \%$ on the $\mathrm{K} 4$ plot with compacted silt loam soil. Similarly, this trend occurred on the conditioned test plots with clay soil, where the highest $\Delta \mathrm{f}$ value was on the vegetated soil (L1) with $50 \%$ and the lowest was on the compacted soil (L4) with $-97 \%$. Based onthe soil conditioning in test plots, the highest constant infiltration rate was on the vegetated plots (K1 \& L1), followed by control or bare plots (K3 \& L3), vegetated and compacted plots (K2 \& L2), and compacted plots (K4 \& L4).

When the data were reviewed by the effect of compaction only, the compacted had a lower constant infiltration rate than the uncompacted control plots. In the Kenjeran Beach Amusement Park, the constant infiltration rate in the K4 plot was $33.16 \%$ smaller than the K3. Meanwhile, in the Lempung City Forest, the constant infiltration rate in the L4 plot was 97\% smaller than in the L3. The results showed that the soil compaction had a significant effect to reduce the constant infiltration rate in Lempung Urban Forest with clay textured soil compared with the Kenjeran Beach Amusement Park with silt-textured soil. Similarly, these results are confirmed in research by Aziz et al. (2017) that analyzed the effect of the sand fraction on several variables such as soil density in the play yard. The research used the compaction in the play yard and measured the infiltration rate of the plots with varying sand fractions, which led to a decrease in soil infiltration rate on every test plot. Furthermore, several types of researches conducted by Andayono (2018) and Dong et al. (2019) have implemented various compaction levels, which showed that higher compaction level lowers the soil infiltration rate. This is in line with the research conducted by Gregory et al. (2006) which stated that soil compaction activities affect its physical properties, while the strength and density are increased and the porosity, as well as the distribution of pores, are reduced. Therefore, the water infiltrated into the soil becomes smaller.

From the presence of vegetation cover, the vegetated plots had a higher constant infiltration rate than others that were without cover. At Kenjeran Beach Amusement Park, the constant infiltration rate in $\mathrm{K} 1$ was $302 \%$ higher than in the K3 plot. Furthermore, in the Lempung City Forest, the constant infiltration rate in the L1 was 50\% higher than in the L3 plot. These results showed that the presence of vegetation cover had a significant effect on enhancing the constant infiltration rate in Kenjeran Beach Amusement Park with silt-textured soil compared with the Lempung Urban Forest with clay texture. Similarly, previous research 
by Regüés et al. (2017) confirmed that vegetation cover on the soil increases the infiltration rates, where all vegetated lands have a higher average infiltration rate compared with the bare land that has an average rate of approximately $103.36 \mathrm{~mm} / \mathrm{h}$. This occurred due to the typical surface sealing in the type of land, compared with the vegetated lands that have larger pore holes.

In the plots that combined the variable vegetation cover with compaction, the constant infiltration rate was smaller, which was approximately equal to the rate of the control plot in the silt loam soil and decreased compared with the control plot in the clay soil. Furthermore, the presence of vegetation on compacted soil has no significant effect on the increase of the infiltration rate. However, this figure was still higher than the test plots which were only compacted and not vegetated. In Kenjeran Beach Amusement Park, the constant infiltration rate in the K2 was the same as the K3 plot. Meanwhile, in Lempung City Forest, the constant infiltration rate in the L2 plot was $87.5 \%$ lower than in the L3. These results showed that the type of soil conditioning had a significant effect on reducing the constant infiltration rate in Lempung Urban Forest with clay textured soil, although, it was still higher compared to the plot with soil compaction only (L4). For the Kenjeran Beach Amusement Park with silt loam textured soil, the conditioning has no significant difference on the constant infiltration rate. Based on the field measurements in Kenjeran Beach Amusement Park, especially at the first 15 minutes, the infiltration rate in the K2 plot was higher than in the control (K3).

Moreover, similar research on the analyzes of soil infiltration rate with these vegetated and compacted plots or with the green urban areas has also been conducted by Coutinho et al. (2020) and Zhang et al. (2020). In the research by Coutinho et al. (2020), the infiltration measurements were carried out in the public infrastructures that consist of gardens, children's recreation, and communal areas where each place has a different soil texture and only the gardens were vegetated. The highest infiltration rate was in the garden, followed by children's recreation, and communal areas. In previous research by Zhang et al. (2020), the infiltration measurements were carried out in the park, square, block, and other shared spaces, which are vegetated and compacted, but the type of soil texture is unknown. The highest constant infiltration rate was on the park, followed by square, block, and other shared space. Based on the analysis using SPSS, the permeability of the soil in different green areas is influenced by several factors such as bulk density, moisture content, and noncapillary porosity. 


\subsection{Comparisons of Soil Infiltration Measurements on and Modeled Soil Infiltration}

The comparison between the modeled infiltration capacity formed using the Horton method and the measurement of the infiltration rate in the field was carried out to determine the significant difference between the two values, especially when at the constant state. Therefore, the modeled infiltration capacity was used as a benchmark because it predicts the maximum rate of water that infiltrates into the soil. The visualized differences between the modeled infiltration rate and the field measurement are shown in Figure 5.

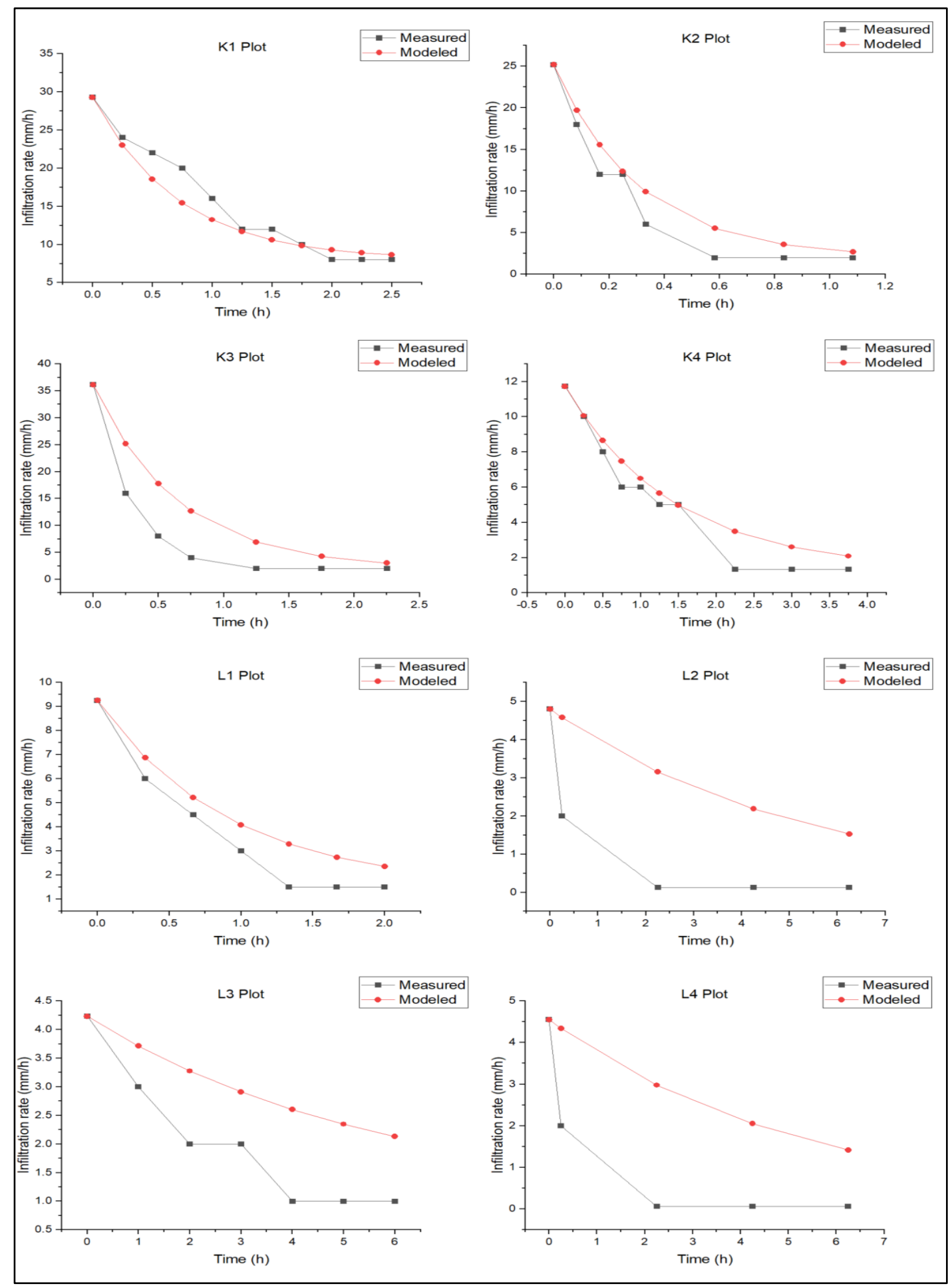

Figure 5. The comparisons between measured and modeled infiltration rates in test plots 
Based on Figure 5, there are some differences between the modeled infiltration rate using the Horton equation with the actual infiltration rate in the test fields, where the actual rates were consistently lower than the modeled, with an exception at the K1 plot. At that plot during the first one hour from the time $t=0$ and from the $t=1.25-1.5 \mathrm{~h}$, the field measurements were higher compared with the predicted infiltration rate. The average difference between the modeled infiltration curve with the measured infiltration curve is shown in Table 7.

Table 7. The average difference between the modeled infiltration curve with the measured infiltration curve

\begin{tabular}{cc}
\hline Test plot & $\begin{array}{c}\text { The average difference between curves } \\
(\mathbf{m m} / \mathbf{h})\end{array}$ \\
\hline K1 & 1.502 \\
K2 & 1.920 \\
K3 & 5.153 \\
K4 & 0.755 \\
L1 & 0.940 \\
L2 & 1.813 \\
L3 & 0.997 \\
L4 & 1.719 \\
\hline
\end{tabular}

Based on Table 7, it was shown that the differences between the measured infiltration curves with the modeled varied on each test plot. Meanwhile, the plots that have average differences under $1 \mathrm{~mm} / \mathrm{h}$ were the K4 plot, L1 plot, and L3 with approximately $0.755 \mathrm{~mm} / \mathrm{h}$, $0.940 \mathrm{~mm} / \mathrm{h}$, and $0.997 \mathrm{~mm} / \mathrm{h}$, respectively. However, some plots such as K1, K2, L2, and L4 have a large average difference which ranged from 1.5 to $1.9 \mathrm{~mm} / \mathrm{h}$. The largest average difference occurred on the $\mathrm{K} 3$ plot with a value of $5.153 \mathrm{~mm} / \mathrm{h}$. This showed that the measured infiltration rates in the test plots were significantly smaller compared with the predicted rate modeled by Horton's equation.

According to Vereecken et al. (2019), this occurred because the infiltration rate measurements from the test locations are affected by the changes in the soil profile conditions. This depends on the time of the infiltration measurements, which are related to the initial soil water content and weather dynamics. When this research was conducted, Surabaya City was in the rainfall season, which showed that the probability of the initial water content in the soil profile on both test fields was high. Since the city is in the tropical climate zone, the weather changes from rainy to sunny condition occurs frequently. 


\subsection{Potential Constant Infiltration Capacity from the Test Plots}

Based on the calculations using Horton's equation, the potential of constant infiltration rate from the test plots is predicted. Therefore, the potential runoff generated from these places is determined, one of which is by classifying the potential constant infiltration rates by using the USDA hydrologic soil group as shown in Table 2. The potential constant infiltration rate from each plot and their classifications are shown in Table 8.

Table 8 . The classification of the potential constant infiltration rate from test plots

\begin{tabular}{cccc}
\hline Test plot & $\begin{array}{c}\text { The potential constant } \\
\text { infiltration rate } \\
(\mathbf{m m} / \mathbf{h})\end{array}$ & USDA soil group & Runoff potential \\
\hline K1 & 8.638 & $\mathrm{~A}$ & Low rate \\
K2 & 2.698 & $\mathrm{C}$ & Moderate rate \\
K3 & 3.040 & $\mathrm{C}$ & Moderate rate \\
K4 & 2.086 & $\mathrm{C}$ & Moderate rate \\
L1 & 2.362 & $\mathrm{C}$ & Moderate rate \\
L2 & 1.525 & $\mathrm{C}$ & Moderate rate \\
L3 & 2.130 & $\mathrm{C}$ & Moderate rate \\
L4 & 1.416 & $\mathrm{D}$ & High rate \\
\hline
\end{tabular}

Based on Table 8, the highest potential constant infiltration rate is $8.638 \mathrm{~mm} / \mathrm{h}$ on the $\mathrm{K} 1$ plot, while the lowest one is $1.416 \mathrm{~mm} / \mathrm{h}$ on the $\mathrm{L} 4$. From all test plots available, 1 plot (K1) is classified as the A group with low runoff potential, 6 plots $(\mathrm{K} 2, \mathrm{~K} 3, \mathrm{~K} 4, \mathrm{~L} 1, \mathrm{~L} 2$, and L3) as the C group with moderate, and 1 plot (L4) as the D group with high runoff potential.

The plots that have a similar characteristic with the urban green areas, which are the $\mathrm{K} 2$ and L2, have the potential constant infiltration rate of approximately $2.698 \mathrm{~mm} / \mathrm{h}$ and $1.525 \mathrm{~mm} / \mathrm{h}$, respectively. These plots have a moderate potential to generate surface runoff in the rainy season based on the USDA hydrologic soil classifications. Meanwhile, the difference between these urban green areas with compacted plots (K4 and L4) is the presence of the vegetation covers, which tends to improve the infiltration on the green urban areas that have a high bulk density from the anthropogenic activities. Although the runoff potentials of K2 and L2 are categorized as moderate, the potential infiltration rates on these plots are closer to the high runoff category. Therefore, some options to improve the soil permeability in urban green areas need to be considered by the local government.

\section{Conclusion}

Based on the soil conditioning tested in this research, the infiltration rate is increased on the vegetated plots in both silt loam and clay textured soil. The combination of vegetation and soil compaction slightly decreased the infiltration rate in the clay textured soil, but there 
was no difference in the silt loam A significant decrease in the infiltration rate occurred on the compacted plots only in silt loam and clay textured soil. The effect of vegetation cover is more significant in silt loam, while the influence of compaction is more impactful on the clay textured soil. Also, the potential constant infiltration rate from the plots of similar characteristics with green urban areas are on the K2 and L2 with approximately $2.698 \mathrm{~mm} / \mathrm{h}$ and $1.525 \mathrm{~mm} / \mathrm{h}$, respectively. For classifications based on USDA hydrologic soil group, the K2 and L2 plots have a moderate runoff potential. Therefore, for further research, more variations in soil compaction and texture on the vegetated land are to be analyzed to better understand the soil's ability to infiltrate through the soil profile on the green urban facilities.

\section{Acknowledgements}

The authors are grateful to all departments involved in Surabaya (Department of Public Works, Highways and Drainage; Department of Culture and Tourism, and Department of Food Security and Agriculture) for providing the information needed and the permission to use some urban facilities for this research. Furthermore, the author is to parents and friends for finalizing this research within the limited time frame.

\section{Conflict of interest}

The authors declare no conflict of interest.

\section{References}

Andayono, T. (2018). The Effect of Soil Density on Infiltration Rate in The Urban Development Area of Padang. Jurnal Teknik Sipil Dan Perencanaan, 20(1), 1-5. https://doi.org/10.15294/jtsp.v20i1.12387.

Apollonio, C., Balacco, G., Novelli, A., Tarantino, E., \&Piccinni, A. (2016). Land Use Change Impact on Flooding Areas: The Case Study of Cervaro Basin (Italy). Sustainability, 8(10), 996. https://doi.org/10.3390/su8100996.

Aziz, S. A., Rasheed, A. M., \& Taha, Z. Y. (2017). Effect of sand fractions on sandy soil peat mixture, and irrigation intervals, infiltration rate, bulk density and grass performance in play yard. Journal of ZankoySulaimani - Part A,19(2), 53-60. https://doi.org/10.17656/jzs.10611.

Coutinho, A. P., França, E. G., Ribeiro Neto, A., Melo, T. A. T., Santos Neto, S. M., Barros, V. H. O., Alcântara, L. R. P., \& Antonino, A. C. D. (2020). Behavior of water infiltration phenomenon in soil in an urban park. Revista de Gestão de Água da América Latina, 17(7). https://doi.org/10.21168/rega.v17e7. 
Dong, Q. G., Han, J.C., Zhang, Y., Li, N., Lei, N., Sun, Z.H., Du, Y.C., \& He, J. (2019). Water Infiltration of Covering Soils with Different Textures and Bulk Densities In Gravel-mulched Areas. Applied Ecology and Environmental Research, 17(6). https://doi.org/10.15666/aeer/1706_1403914052.

Folorunso, O., \& Aribisala, J. (2018). Effect of Soil Texture on Soil Infiltration Rate. Archives of Current Research International, 14(3), 1-8. https://doi.org/10.9734/acri/2018/41974.

Gregory, J.H., Dukes, M.D., Jones, P.H., \& Miller, G.L. (2006). Effect of urban soil compaction on infiltration rate. Journal of Soil and Water Conservation, 61(3), 117124.

Gundalia, M. (2018). Estimation of infiltration rate based on complementary error function peak for Ozat watershed in Gujarat (India). International Journal of Hydrology, 2(3). 289-294. https://doi.org/10.15406/ijh.2018.02.00083.

Hwang, Y. H., Nasution, I. K., Amonkar, D., \&Hahs, A. (2020). Urban Green Space Distribution Related to Land Values in Fast-Growing Megacities, Mumbai and JakartaUnexploited Opportunities to Increase Access to Greenery for the Poor. Sustainability, 12(12), 4982. https://doi.org/10.3390/su12124982.

McGrane, S.J. (2016). Impacts of urbanisation on hydrological and water quality dynamics, and urban water management: a review. Hydrological Sciences Journal, 61(13), 22952311. https://doi.org/10.1080/02626667.2015.1128084.

Ma, W., Zhang, X., Zhen, Q., \& Zhang, Y. (2016). Effect of soil texture on water infiltration in semiarid reclaimed land. Water Quality Research Journal of Canada, 51(1), 33-41. https://doi.org/10.2166/wqrjc.2015.025.

Marie Mireille, N., M. Mwangi, H., K. Mwangi, J., \& Mwangi Gathenya, J. (2019). Analysis of Land Use Change and Its Impact on the Hydrology of Kakia and Esamburmbur SubWatersheds of Narok County, Kenya. Hydrology, 6(4), 86. https://doi.org/10.3390/hydrology6040086.

Patle, G. T., Sikar, T. T., Rawat, K. S., \& Singh, S. K. (2018). Estimation of infiltration rate from soil properties using regression model for cultivated land. Geology, Ecology, and Landscapes, 3(1), 1-13. https://doi.org/10.1080/24749508.2018.1481633.

Qing, X., Haojie, H., Jinran, X., Caixia, Z., Zhiliang, Z., Huiqiang, H., \& Qin, Z. (2020). Research Progress of Soil Water Infiltration. Paper presented at the 2020 International Conference on Agricultural Science and Technology and Food Engineering (ASTFE 2020). Changchun, China.

Regüés, D., Badía, D., Echeverría, M. T., Gispert, M., Lana-Renault, N., León, J., ... Serrano-Muela, P. (2017). Analysing the effect of land use and vegetation cover on soil infiltration in thee contrasting environments in northeast Spain. Cuadernos de InvestigaciónGeográfica, 43(1), 141. https://doi.org/10.18172/cig.3164. 
Satheeshkumar, S., Venkateswaran, S., \& Kannan, R. (2017). Rainfall-runoff estimation using SCS-CN and GIS approach in the Pappiredipatti watershed of the Vaniyar sub basin, South India. Modeling Earth Systems and Environment, 3(1). doi:10.1007/s40808-017-0301-4.

Schoeneberger, P.J., Wysocki, D.A., Benham, E.C. \&Soil Survey Staff. (2012). Field Book for Describing and Sampling Soils: Version 3.0. Lincoln, NE: Natural Resources Conservation Service.

Sucahyanto, S., Setiawan, C., \& Septiani, R. (2018). Land Cover Changes and Its Effect to Sediment Growth in Cacaban Reservoir, Tegal District, Central Java Province, Indonesia. Paper presented at the 1st UPI International Geography Seminar 2017.Bandung, Indonesia.

Vereecken, H., Weihermüller, L., Assouline, S., Šimůnek, J., Verhoef, A., Herbst, M., ... Xue, Y. (2019). Infiltration from the Pedon to Global Grid Scales: An Overview and Outlook for Land Surface Modeling. Vadose Zone Journal, 18(1), 1-53. https://doi.org/10.2136/vzj2018.10.0191.

Zemke, J. J., Enderling, M., Klein, A., \&Skubski, M. (2019). The Influence of Soil Compaction on Runoff Formation. A Case Study Focusing on Skid Trails at Forested Andosol Sites. Geosciences, 9(5), 204. https://doi.org/10.3390/geosciences9050204.

Zhang, L., Wang, C., Liang, G., Cui, Y., \& Zhang, Q. (2020). Influence of Land Use Change on Hydrological Cycle: Application of SWAT to Su-Mi-Huai Area in Beijing, China. Water, 12(11), 3164. https://doi.org/10.3390/w12113164.

Zhang, Y., Cao, F., Huang, L., Zhou, Y., \& Yang, Z. (2020). Comparative Study and Simulation of Soil Infiltration Performance in Open Green Space. TehnickiVjesnik Technical Gazette, 27(3). https://doi.org/10.17559/tv-20191230171234. 